\title{
PERBEDAAN PENGUASAAN KONSEP DAN KEMAMPUAN SISWA DALAM MEMBUAT PETA KONSEP ANTARA PENERAPAN STRATEGI MENGGARISBAWAHI DAN STRATEGI 3R (READ-RECITE-REVIEW)
}

\author{
Ratna Diyah Mustikawati ${ }^{1)}$ \\ Yuni Sri Rahayu ${ }^{2)}$ \\ Tjandrakirana ${ }^{2)}$ \\ 1)Mahasiswa Pascasarjana Prodi Pendidikan Sains Universitas Negeri Surabaya \\ 2)Dosen Pascasarjana Prodi Pendidikan Sains Universitas Negeri Surabaya
}

\begin{abstract}
In reality, the score in science subject of RSBI students' was unsatisfied, so that a research was conducted. The aim of this research was to differentiate the concept comprehension and the student ability in concept map between the implementation of underlining and $3 R$ strategies. The research sample was 32 students from two groups that were underlining and $3 R$ strategies using pretest-posttest control group design. Data were analyzed using t test $(\alpha=0,05)$. The result of this research proved that the concept comprehension and the concept map increased in both strategies. There was difference in the concept comprehension between two strategies $(p=0,018)$ but there was no difference in the concept map $(p=0,221)$. They also shown that self assessment for student skill strategy and student respond in good categories, and the implementation of lesson plan was in very good category. The research revealed that there were differences between two strategies for concept comprehension, but the students' ability in concept map were no differ
\end{abstract}

Key Words: concept map, 3R strategies, Underlining

\begin{abstract}
Abstrak. Kenyataan di lapangan nilai siswa RSBI pada mata pelajaran IPA belum memuaskan, maka dilakukan penelitian yang bertujuan untuk membedakan penguasaan konsep dan peta konsep siswa. Sampel penelitian 32 siswa dari dua kelompok yaitu kelompok strategi menggarisbawahi dan kelompok strategi $3 R$ dengan rancangan pretest-posttest control group design. Data dianalisis melalui uji $t(\alpha=0,05)$. Hasil penelitian menunjukkan nilai penguasaan konsep maupun skor peta konsep meningkat pada masing-masing strategi. Ada perbedaan nilai penguasaan konsep antara kedua strategi $(p=0,018)$ namun tidak ada perbedaan skor peta konsep $(p=0,22)$. Selain itu didapatkan pula hasil penilaian diri keterampilan strategi siswa dan respon siswa dalam kategori baik serta keterlaksanaan RPP dengan hasil sangat baik. Simpulan penelitian didapatkan, untuk penguasaan konsep berbeda antara kedua strategi, sedangkan kemampuan siswa dalam membuat peta konsep tidak berbeda.
\end{abstract}

Kata kunci: strategi menggarisbawahi, strategi 3R, penguasaan konsep, peta konsep.

\section{PENDAHULUAN}

Untuk meningkatkan kualitas dan daya saing bangsa Indonesia dalam era globalisasi, pemerintah telah melakukan beberapa upaya. Salah satunya adalah menyelenggarakan rintisan sekolah bertaraf internasional (RSBI) di setiap jenjang pendidikan termasuk Sekolah Menengah Pertama (SMP). Sehubungan dengan hal tersebut, diharapkan SMP RSBI dapat menyelenggarakan pembelajaran yang berkualitas dalam bahasa Inggris, terutama untuk mata pelajaran MIPA- Matematika dan Ilmu Pengetahuan Alam atau IPA (Direktorat PSMP, $2010: 3$ ).

Salah satu sekolah RSBI adalah SMP Negeri 1 Sidoarjo yang ditetapkan sebagai RSBI sejak tahun 2007. Ketika siswa-siswa di sekolah tersebut diuji secara nasional untuk mata pelajaran Matematika dan Ilmu Pengetahuan Alam oleh Direktorat Pendidikan Sekolah Menengah Pertama ternyata hasilnya kurang memuaskan, terutama untuk mata pelajaran IPA.
Hasil perolehan siswa dalam tes di atas memunculkan asumsi bahwa siswa belum memahami konsep-konsep IPA dalam bahasa Inggris. Oleh karena itu, pembelajaran IPA di kelas RSBI seharusnya lebih sering memfasilitasi siswa untuk membaca literatur IPA dalam bahasa Inggris dan menjadikan pengetahuan dalam literatur tersebut milik siswa sendiri (Brooks, 1990 dalam Nur, 2008:2). Guru dapat membantu proses ini, dengan memberikan kesempatan kepada siswa untuk menemukan atau menerapkan sendiri ide-ide, dan dengan mengajak siswa agar menyadari dan secara sadar menggunakan strategi-strategi mereka sendiri untuk belajar (Nur dan Wikandari, 2008:2)

Strategi belajar yang sering dilakukan adalah strategi mengulang. Strategi mengulang sangat penting dalam belajar, karena semakin lama suatu informasi tinggal dalam memori jangka pendek semakin besar kemungkinan informasi tersebut akan ditransfer ke memori jangka panjang (Nur, 2008:12). Menggarisbawahi ide pokok merupakan salah satu 
strategi mengulang kompleks yang dapat diajarkan kepada siswa (Nur, 2005:27). Salah satu modifikasi dari strategi mengulang adalah strategi read-recite-review (3R). Langkah-langkah dalam strategi 3R adalah Read (membaca), Recite (menyebutkan), dan Review (membaca ulang). Strategi ini merupakan penyederhanaan dari strategi SQ3R yang dikembangkan oleh Robinson (McDaniel, 2009).

Strategi 3R dipilih karena beberapa ciri dalam tahap-tahap 3R menjanjikan bahwa strategi ini efektif, yaitu 3R mudah diajarkan kepada siswa daripada strategi SQ3R yang utuh dan mudah diterapkan oleh siswa. Demikian juga strategi $3 \mathrm{R}$ melibatkan pengulangan kembali segera setelah belajar (tahap review), suatu kondisi yang memaksimalkan jumlah penerimaan informasi (Kang et al., 2007 dalam McDaniel, 2009).

Berdasarkan latar belakang permasalahan di atas, maka penelitian ini adalah membedakan tujuan yang ingin dikaji dalam penguasaan konsep dan kemampuan siswa dalam membuat peta konsep setelah penerapan strategi menggarisbawahi dan strategi 3R"

\section{METODE PENELITIAN}

\section{Subyek dan Prosedur Penelitian}

Penelitian ini merupakan penelitian eksperimen dengan rancangan pretest-postest control group design.Penelitian dilakukan pada 2 kelompok sampel yang masing-masing terdiri dari 16 siswa dari 2 kelas VII yang berbeda. Pemilihan siswa dalam kelompok sampel dilakukan secara acak. Di awal penelitian semua kelompok mendapat perlakuan pretes yaitu soal pilihan ganda dan membuat peta konsep tentang Organisasi Kehidupan pada selembar kertas kosong.

Pada kelompok pertama, siswa diberi bacaan dan diminta untuk membaca, selama membaca ide-ide penting dalam bacaan tersebut diminta untuk diberi garis bawah atau diberi tanda dengan spidol berwarna. Kelas kedua ditetapkan sebagai kelompok eksperimen 2, siswa diberi bacaan dan diminta untuk menerapkan strategi 3R membaca bacaan tersebut satu kali, kemudian diminta untuk mengucapkan ide-ide penting yang mereka temukan dalam bacaan, setelah itu diminta untuk membaca kembali bacaan tersebut.

Penelitian dilaksanakan dalam dua kali pertemuan, yang masing-masing pertemuan terdiri dari tiga kali empat puluh menit. Pada masing-masing pertemuan semua kelompok mendapat pengajaran tentang materi Organisasi Kehidupan dengan menerapkan strategi belajar yang dirancang pada masing-masing kelompok, kemudian di akhir proses pembelajaran siswa dibimbing untuk membuat peta konsep dari materi yang telah dipelajari pada pertemuan tersebut.
Setelah pertemuan kedua berakhir siswa diberi tes tertulis. Selesai mengerjakan tes tertulis, siswa diberi selembar kertas dan diminta untuk membuat peta konsep pada kertas tersebut tentang materi Organisasi Kehidupan yang telah mereka pelajari.

\section{Instrumen Pengambilan Data}

Penelitian ini menggunakan tiga teknik pengambilan data, yaitu tes tertulis untuk penguasaan konsep dan kemampuan siswa dalam membuat peta konsep, observasi untuk pengamatan keterlaksanaan RPP, dan angket untuk respon dan keterampilan siswa dalam menerapkan strategi yang diajarkan.

Tes penguasaan konsep siswa berfungsi untuk mengukur pemahaman siswa terhadap konsep, fakta, dan prinsip dalam materi organisasi kehidupan. Bentuk tes penguasaan konsep yang dikembangkan adalah tes tertulis dengan soal pilihan ganda sebanyak sepuluh butir soal. Nilai diperoleh dari skor yang diperoleh dibagi skor maksimum dan dikalikan 100.

Penilaian peta konsep siswa menggunakan penilaian secara kuantitatif dengan metode yang dikembangkan oleh Novak dan Gowin (dalam Ozdemir, 2005).

Keterlaksanaan RPP diamati dalam pelaksanaan pada kegiatan pendahuluan, kegiatan inti, dan kegiatan penutup dengan menggunakan lembar observasi. Penilaian menggunakan 5 skala dari sangat baik ke sangat kurang (Tuckman, 1978).

Penilaian keterampilan strategi siswa merupakan lembar penilaian diri terhadap kemampuan siswa dalam menerapkan keterampilan menggarisbawahi atau 3R yang diajarkan. Angket respon siswa berupa lembaran yang memuat tabel dengan mencantumkan komponenkomponen tanggapan siswa terhadap proses pembelajaran dan kemampuan guru. Skala yang ditetapkan 4 (sangat baik), 3 (baik), 2 (cukup), dan 1 (kurang).

\section{Pengujian Instrumen \\ Validitas Instrumen}

Validitas suatu instrumen diperlukan untuk mengetahui bahwa instrumen yang digunakan dapat mengukur apa yang hendak diukur (Sukardi, 2007:122). Validitas yang dipakai dalam penelitian ini adalah validitas isi dan validitas konstruk. Validitas ini dilakukan bertujuan untuk menentukan kesesuaian antara soal dengan Standar Kompetensi dan Kompetensi Dasar yang dipilih. Validasi instrumen dilakukan dengan mengadakan kajian teori dan dikonsultasikan kepada validator yang kompeten di bidangnya (Jihad dan Haris, 2008:179).

\section{Reliabilitas Instrumen}

Suatu instrumen penelitian dikatakan mempunyai nilai reliabilitas tinggi, apabila instrumen yang dibuat 
mempunyai hasil yang konsisten dalam mengukur yang hendak diukur (Sukardi, 2007:127).

Reliabilitas soal tes merupakan ukuran yang menyatakan tingkat keajegan atau kekonsistenan suatu soal tes. Untuk mengukur tingkat keajegan soal ini digunakan rumus Alpha Cronbach. Rumus yang digunakan dinyatakan dengan (Jihad dan Haris, 2008:180):

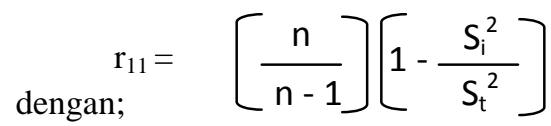

$\mathrm{n}=$ banyaknya butir soal

$\mathrm{S}_{\mathrm{i}}^{2} \quad=$ jumlah varians skor tiap item

$\mathrm{S}_{\mathrm{t}}^{2} \quad=$ varians skor total

Rumus untuk mencari varians adalah:

$$
\mathrm{S}_{\mathrm{i}}{ }^{2}=\frac{\sum \mathrm{X}^{2}-\frac{\left(\sum X\right)^{2}}{\mathrm{n}}}{\mathrm{n}}
$$

Interpretasi nilai $r_{11}$ mengacu pada pendapat Guilford (Ruseffendi, 1991 dalam Jihad dan Haris, 2008:181):

$$
\begin{array}{lll}
r_{11} & \leq 0,20 & : \text { sangat rendah } \\
0,20 & <r_{11}<0,40 & : \text { rendah } \\
0,40 & <r_{11}<0,70 & : \text { sedang } \\
0,70 & <r_{11}<0,90 & : \text { tinggi } \\
0,90 & <r_{11}<1,00 & : \text { sangat tinggi }
\end{array}
$$

Penilaian peta konsep dilakukan oleh dua orang pada awal penelitian dan di akhir penelitian. Untuk melihat kecocokan hasil penilaian, dilakukan perhitungan reliabilitas dengan menggunakan rumus percentage of agreements (Emmer and Millet, 1970 dalam Borich, 1994:385) sebagai berikut:

$$
\begin{aligned}
& \mathrm{R}=100 \% \\
& \text { dengan; }
\end{aligned} \quad 1-\left(\frac{A-B}{A+B}\right)
$$

$\mathrm{R}$ : reliabilitas instrumen

$A$ : frekuensi tertinggi pengamatan

$B$ : frekuensi terendah pengamatan

Instrumen dikatakan reliabel jika nilai reliabilitas yang diperoleh $(\mathrm{R}) \geq 0,75$ (Borich, 1994:385).

Proses pembelajaran strategi belajar diamati oleh dua orang guru untuk mengamati keterlaksanaan tahaptahap pembelajaran yang telah direncanakan dengan model pembelajaran langsung. Untuk melihat kesamaan hasil pengamatan juga dilakukan perhitungan reliabilitas dengan menggunakan rumus percentage of agreements dengan kategori di atas $75 \%$ instrumen dikatakan reliabel atau baik (Borich, 1994:385).

\section{Analisis Data}

Penelitian ini menggunakan analisis deskriptif dan statistik inferensial. Analisis deskriptif difungsikan untuk pengambilan kesimpulan atas kecenderungan data. Analisis Statistik inferensial difungsikan untuk pengambilan keputusan atas gejala yang terdapat pada populasi menggunakan data yang terkumpul pada sampel (Amir, 2006).

Pada penelitian ini untuk menganalisis kecenderungan data tes penguasaan konsep maupun skor peta konsep, dan data hasil pengamatan keterlaksanaan rencana pembelajaran, data hasil penilaian diri keterampilan strategi siswa, serta data hasil angket respon siswa terhadap proses pembelajaran, menggunakan analisis deskriptif kuantitatif dan kualitatif. Untuk pengujian hipotesis yaitu membedakan hasil tes penguasaan konsep dan skor peta konsep antara penerapan dua strategi menggunakan analisis statistik inferensial dengan menggunakan Independent Sample TTest. Pengujian memanfaatkan program komputer SPSS 15 for Windows.

Perubahan struktur peta konsep yang dibuat siswa dianalisis dengan menggunakan selisih (gain) skor postes dan pretes. Untuk menganalisis peningkatan penguasaan konsep digunakan gain-score ternormalisasi, dengan rumus sebagai berikut (Hake, 1999):

$\left.\left.\langle g\rangle=\left(\%<\mathrm{S}_{\mathrm{f}}\right\rangle-\%\left\langle\mathrm{~S}_{\mathrm{i}}\right\rangle\right) /\left(100-\%<\mathrm{S}_{\mathrm{i}}\right\rangle\right)$ dengan; $\left\langle\mathrm{S}_{\mathrm{f}}\right\rangle$ : rata-rata postes dan $\left\langle\mathrm{S}_{\mathrm{i}}\right\rangle \quad$ : rata-rata pretes

Tingkat perolehan gain score ternormalisasi dikategorikan ke dalam tiga kategori (Hake, 1999), yaitu:

$$
\begin{aligned}
& g \text {-tinggi; dengan }(\langle g\rangle)>0,7 \\
& g \text {-sedang; dengan } 0,7>(<g\rangle)>0,3 \\
& \quad g \text {-rendah; dengan }(\langle g\rangle)<0,3
\end{aligned}
$$

\section{HASIL DAN PEMBAHASAN}

\section{A. HASIL \\ Deskripsi Validasi Perangkat Pembelajaran}

Validasi dilakukan terhadap perangkat pembelajaran untuk memperoleh saran dari pakar yang kompeten dibidangnya sebagai acuan untuk merevisi perangkat yang dikembangkan. Validasi dilakukan pada semua perangkat pembelajaran yang dikembangkan, meliputi silabus, RPP, buku siswa (bahan bacaan), lembar kerja siswa, dan alat evaluasi.

Tabel 1. Hasil Validasi Perangkat Pembelajaran

\begin{tabular}{|c|l|c|c|c|c|c|c|}
\hline \multirow{2}{*}{ No } & \multirow{2}{*}{ Perangkat Pembelajaran } & \multicolumn{5}{|c|}{ Validator } & \multirow{2}{*}{ Rata-rata } \\
\cline { 3 - 7 } & & 1 & 2 & 3 & 4 & 5 & \\
\hline 1. & Silabus & 3,8 & 3,5 & 3,7 & 3,7 & 3,8 & 3,70 \\
\hline 2. & Rencana Pelaksanaan Pembelajaran & 3,8 & 3,8 & 3,7 & 3,7 & 3,7 & 3,74 \\
\hline 3. & Lembar Kerja Siswa & 3,8 & 3,5 & 3,7 & 3,7 & 3,7 & 3,68 \\
\hline
\end{tabular}


4. $\quad$ Buku Siswa

Dari data hasil validasi pada tabel tersebut dapat diartikan bahwa perangkat yang dikembangkan baik dan dapat digunakan.

\section{\begin{tabular}{|l|l|l|l|l|l|}
\hline 3,9 & 3,6 & 3,8 & 3,6 & 3,4 & 3,66 \\
\hline
\end{tabular}}

\section{Hasil Pengamatan Keterlaksanaan RPP}

Pengamatan pembelajaran dilakukan dengan menggunakan instrumen lembar observasi keterlaksanaan RPP dan dilakukan oleh 2 orang pengamat dengan hasil sebagai berikut.

Tabel 2. Perbedaan Rata-rata Skor Hasil Pengamatan Keterlaksanaan RPP Setiap Fase Pembelajaran Pada Masing-masing Kelompok Strategi

\begin{tabular}{|c|c|c|c|c|c|}
\hline \multirow{2}{*}{ No } & \multirow{2}{*}{ Kelompok } & \multirow{2}{*}{ Pertemuan ke- } & \multicolumn{3}{|c|}{ Fase Pembelajaran/Kategori } \\
\hline & & & Pendahuluan & Kegiatan Inti & Penutup \\
\hline \multirow{4}{*}{1} & \multirow{4}{*}{$\begin{array}{l}\text { Strategi } \\
\text { Menggarisbawahi }\end{array}$} & \multirow{2}{*}{1} & 4,8 & 4,4 & 4,5 \\
\hline & & & Sangat baik & Sangat baik & Sangat baik \\
\hline & & \multirow{2}{*}{2} & 5 & 4,6 & 4,5 \\
\hline & & & Sangat baik & Sangat baik & Sangat baik \\
\hline \multirow{4}{*}{2} & \multirow{4}{*}{ Strategi 3R } & \multirow{2}{*}{1} & 4,8 & 4,2 & 4,5 \\
\hline & & & Sangat baik & Sangat baik & Sangat baik \\
\hline & & \multirow{2}{*}{2} & 5 & 4,8 & 4,8 \\
\hline & & & Sangat baik & Sangat baik & Sangat baik \\
\hline
\end{tabular}

Data pada tabel diatas menunjukkan bahwa kualitas pelaksanaan pembelajaran pada kedua kelompok strategi adalah sama baiknya.

\section{Hasil Penilaian Diri Keterampilan Strategi Belajar} Siswa

Rata-rata skor keterampilan strategi siswa pada kedua kelompok strategi dapat dikategorikan baik, yaitu rata-rata skor 3,21 untuk keterampilan strategi menggarisbawahi dan rata-rata skor 3,28 untuk keterampilan strategi 3R. Gambaran hasil penilaian diri keterampilan strategi siswa dapat dilihat pada Gambar 1 di bawah ini.

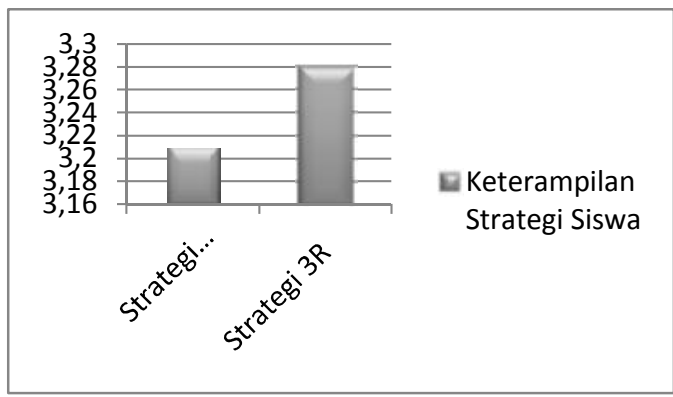

Gambar 1. Diagram Rata-rata Skor Penilaian Diri Keterampilan Strategi Siswa Pada Masing-masing Kelompok Strategi

Hasil Angket Respon Siswa Terhadap Kegiatan Pembelajaran

Skor hasil angket respon siswa pada strategi menggarisbawahi adalah 3,36 dan pada strategi $3 \mathrm{R}$ adalah 3,53. Hasil respon siswa tersebut dapat dikategorikan baik. Data yang diperoleh ditunjukkan dalam Gambar 2 sebagai berikut.

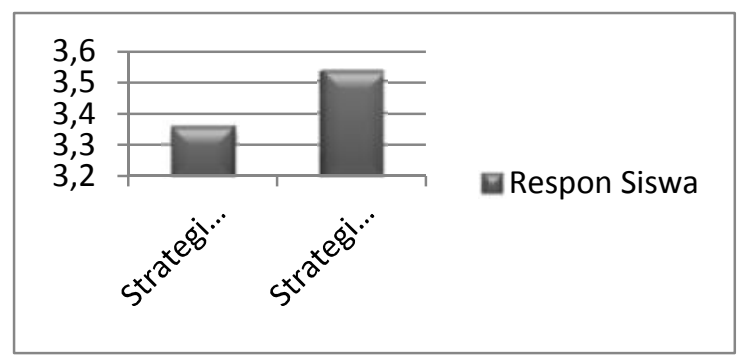

Gambar 2. Diagram Rata-rata Hasil Angket Respon Siswa Pada Masing-masing Kelompok Strategi 
Deskripsi Hasil Pretes dan Postes Penguasaan Konsep dan Skor Peta Konsep

Hasil pretes penguasaan konsep menunjukkan skor rata-rata untuk kelompok strategi menggarisbawahi adalah 35 dan untuk kelompok strategi 3R adalah 40 . Sedangkan postes untuk penguasaan konsep pada strategi menggarisbawahi adalah 74,4 dan 82,5 pada strategi $3 R$.

Rata-rata skor peta konsep pada pretes untuk kelompok strategi menggarisbawahi adalah 16,4, sedangkan untuk kelompok strategi 3R rata-rata skornya ialah 22,5. Hasil postes untuk skor peta konsep pada strategi menggarisbawahi adalah 33,5 dan pada strategi 3R adalah 45,3. Deskripsi perolehan skor rata-rata pretes untuk penguasaan konsep dan peta konsep ditunjukkan pada Gambar 3.

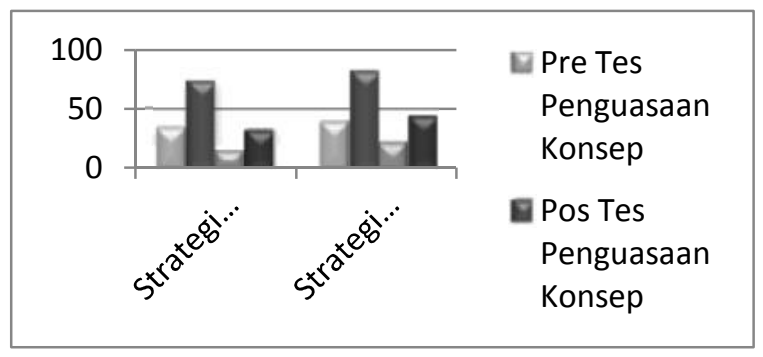

Gambar 3. Diagram Perbedaan Hasil Pretes - Postes Nilai Penguasaan Konsep dan Skor Peta Konsep Untuk Masingmasing Kelompok Strategi

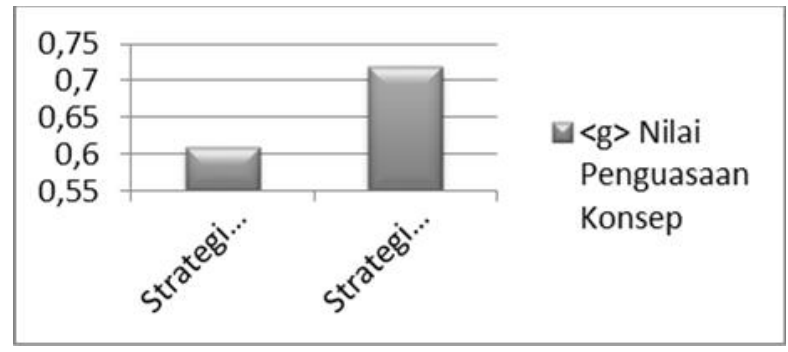

Gambar 4

Diagram Gain Skor Ternormalisasi Penguasaan Konsep Untuk Masing-masing Kelompok Strategi

Selisih (gain) skor postes dan pretes penguasaan konsep dengan menggunakan skor gain ternormalisasi didapatkan $\langle\mathrm{g}\rangle=0,61$ untuk strategi menggarisbawahi yang berarti berada dalam kategori sedang. Dan untuk kelompok strategi 3R didapatkan gain ternormalisasi adalah $\langle\mathrm{g}\rangle=0,72$ yang berarti berada dalam kategori tinggi (Gambar 4).
Secara lebih rinci, didapatkan gain ternormalisasi untuk masing-masing kelompok strategi berada pada kisaran sedang dan tinggi. Kategori rendah tidak didapatkan pada kedua kelompok strategi. Prosentase perolehan gain ternormalisasi untuk masing-masing kelompok strategi ditunjukkan pada Gambar 5 sebagai berikut.

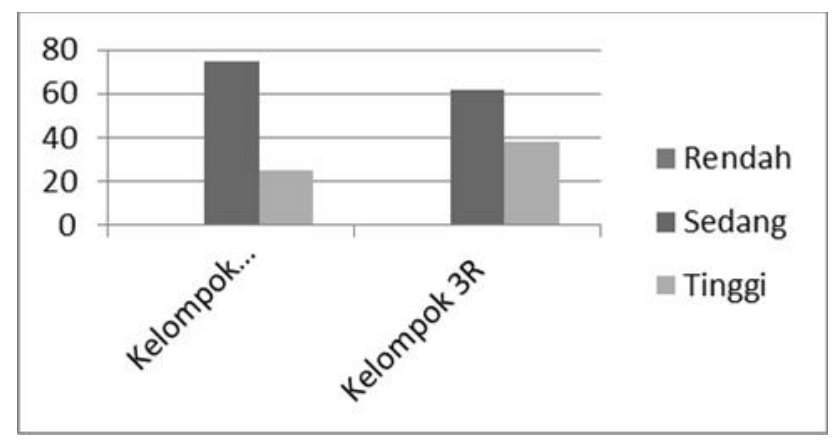

Gambar 5. Prosentase Perolehan Gain Ternormalisasi Untuk Maisng-masing Kelompok Strategi 


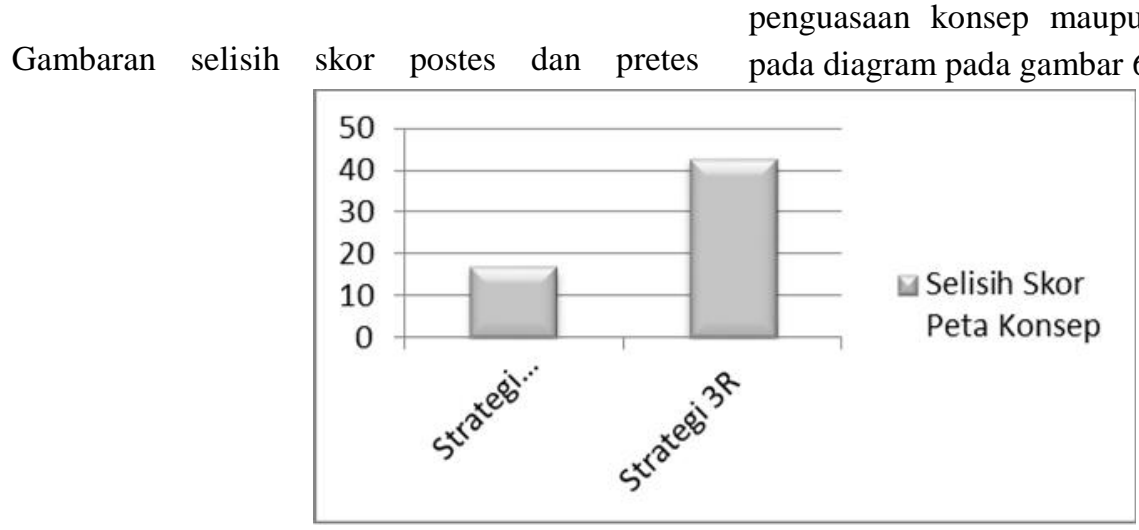

Gambar 6. Diagram Gain Skor Peta Konsep Untuk Masing-masing Kelompok Strategi

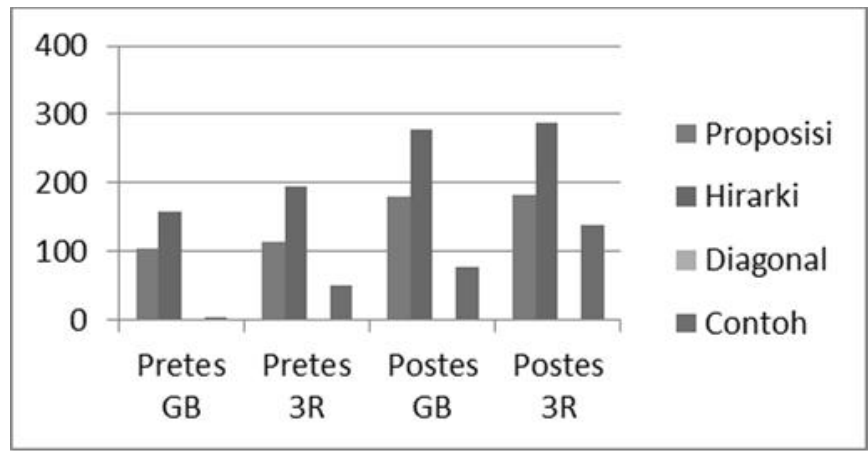

Gambar 7. Diagram Hasil Penilaian Masing-masing Komponen Peta Konsep Pada Kelompok Strategi Menggarisbawahi (GB) dan Strategi 3R

Hasil penilaian peta konsep untuk masing-masing komponen peta konsep dapat dilihat pada Gambar 7. Pada diagram tersebut tampak bahwa komponen diagonal mendapat nilai paling rendah yaitu 0 pada kedua kelompok strategi baik pada pretes maupun postes.

\section{Pengujian Hipotesis}

Dari hasil pengujian dengan KolomogorovSmirnov Test diperolehnilai Asym Sig. adalah 0,478> 0,05 dan 0,450 >0,05. Dengan demikian hasil pengujian dengan analisis non parametrik didapatkan data berdistribusi normal, oleh karena itu dapat dilakukan uji hipotesis dengan menggunakan uji t.

Terkait dengan penelitian eksperimen penerapan strategi menggarisbawahi dan 3R diajukan hipotesis sebagai berikut:

a) $\mathrm{H}_{0}$ : tidak ada perbedaan nilai penguasaan konsep antara penerapan strategi menggarisbawahi dan $3 \mathrm{R}$ $\mathrm{H}_{1}$ : ada perbedaan nilai penguasaan konsep antara penerapan strategi menggarisbawahi dan 3R.

b) $\mathrm{H}_{0}$ : tidak ada perbedaan peta konsep yang dibuat siswa antara penerapan strategi menggarisbawahi dan 3R.

$\mathrm{H}_{1}$ : ada perbedaan peta konsep yang dibuat siswa antara penerapan strategi menggarisbawahi dan 3R.

Berdasarkan hasil analisis uji t $(\alpha=0,05)$ untuk gain nilai penguasaan konsep pada strategi menggarisbawahi dan strategi $3 \mathrm{R}$ diperoleh nilai Sig.
0,18, dengan demikian probabilitas 0,018. Hal ini menunjukkan bahwa terdapat perbedaan gain penguasaan konsep antara strategi menggarisbawahi dan strategi 3R.

Hasil analisis untuk selisih skor peta konsep diperoleh Sig. 0,221 dengan demikian probabilitas 0,221. Kenyataan ini menunjukkan bahwa tidak terdapat perbedaan peta konsep antara kelompok strategi menggarisbawahi dan strategi $3 \mathrm{R}$.

\section{B. PEMBAHASAN}

Hasil Validasi Perangkat Pembelajaran Untuk Mengajarkan Strategi Belajar dengan Model Pembelajaran Langsung

Hasil validasi perangkat pembelajaran merekomendasikan bahwa hal sistematika, rekomendasi tersebut berarti bahwa perangkat yang disusun telah sesuai dengan Peraturan Menteri Pendidikan Nasional Nomor 41 tahun 2007 tentang Standar Proses Untuk Satuan Pendidikan Dasar dan Menengah. Selain itu, hasil tersebut juga menunjukkan bahwa perangkat pembelajaran untuk mengajarkan strategi belajar dengan model pembelajaran langsung adalah valid dan dapat digunakan.

Menurut Westwood (2007:86) strategi belajar diajarkan melalui penjelasan langsung dan pemodelan. Model pembelajaran langsung dirancang secara khusus untuk membelajarkan siswa tentang pengetahuan 
prosedural yang dibutuhkan untuk melaksanakan keterampilan kompleks dan pengetahuan deklaratif yang terstruktur dengan baik dan dapat diajarkan langkah demi langkah (Nur, 2008:26).Dalam rencana pelaksanaan pembelajaran yang dikembangkan telah tercantum langkah-langkah kegiatan untuk melatihkan strategi belajar, demikian juga dengan lembar kerja siswa yang dikembangkan memfasilitasi tahap-tahap dari masingmasing strategi yang diajarkan. Tahap strategi menggarisbawahi telah sesuai dengan penjelasan tentang strategi tersebut dalam Nur (2008:27), yakni menggarisbawahi secara fisik ide-ide kunci suatu paragraf, dan tahap-tahap strategi 3R dalam lembar kerja yang dikembangkan telah sesuai dengan uraian McDaniel (2009), meliputi membaca, resitasi (mengucapkan ide-ide pokok), dan membaca kembali bahan bacaan.

\section{Keterlaksanaan RPP Pada Penerapan Strategi Menggarisbawahi dan Strategi 3R}

Model pembelajaran langsung merupakan sebuah model yang berpusat pada guru yang memiliki lima langkah: mempersiapkan dan memotivasi siswa, menjelaskan dan mendemonstrasikan, latihan terbimbing, umpan balik, dan latihan lanjutan (Nur, 2008:17). Berdasarkan hasil pengamatan terhadap keterlaksanaan RPP mengindikasikan bahwa pelaksanaan pembelajaran strategi belajar dengan model pembelajaran langsung telah memenuhi sintaks-sintaks tersebut.

Rata-rata skor hasil pengamatan pelaksanaan pembelajaran yang ditunjukkan pada kelompok strategi menggarisbawahi maupun kelompok strategi menggarisbawahi berada dalam kategori sangat baik sesuai dengan skala yang telah ditetapkan dalam lembar pengamatan. Hasil yang sangat baik untuk kedua kelompok tersebut juga menunjukkan bahwa kualitas pelaksanaan pembelajaran pada kedua kelompok adalah sama baiknya. Dengan demikian kualitas pelaksanaan pembelajaran bukan menjadi faktor yang mempengaruhi perbedaan hasil tes penguasaan konsep maupun skor peta konsep kedua kelompok strategi.

Keterlaksanaan pembelajaran yang baik memfasilitasi perolehan penguasaan konsep siswa yang baik pula. Hal ini sejalan dengan penelitian yang dilakukan oleh Stalling \& Kaskowitz (1974) dalam Nur (2008:23), mereka menyampaikan temuan yaitu bahwa waktu terjadwal dan penggunaan tugas-tugas spesifik berhubungan kuat dengan penguasaan konsep akademik.

\section{Keterampilan Strategi Belajar Siswa Pada Penerapan Strategi Menggarisbawahi dan Strategi 3R}

Dengan rata-rata skor 3,21 untuk kelompok menggarisbawahi dan 3,28 untuk strategi 3R memberikan gambaran bahwa strategi 3R lebih dapat diterapkan oleh siswa karena strategi ini mempunyai tahap-tahap spesifik yang mudah untuk dilakukan, yaitu membaca, mengucapkan ide-ide penting, dan membaca ulang (McDaniel, 2009).

Rata-rata skor penilaian diri tentang keterampilan strategi yang tergolong baik memberi arti bahwa siswa dapat menerapkan strategi yang diajarkan setelah mendapat pengajaran strategi tersebut dengan model pembelajaran langsung. Pada model pembelajaran tersebut terdapat salah satu fase yaitu memodelkan pengetahuan deklaratif dan prosedural dalam hal ini strategi belajar.

Kategori baik dalam keterampilan strategi siswa ini sesuai dengan teori pembelajaran sosial Albert Bandura. Teori ini menyatakan bahwa banyak dari apa yang dipelajari manusia berasal dari pengamatannya terhadap orang lain. Menurut Bandura (1986), sebagian besar pembelajaran manusia dilakukan dengan secara selektif mengamati dan menempatkan apa yang diamati itu di dalam memori jangka-pendeknya tentang perilaku orang lain itu (Nur, 2008:21).

Menggarisbawahi membantu siswa belajar lebih banyak dari teks karena beberapa alasan. Pertama, menggarisbawahi secara fisik menemukan ide-ide kunci, oleh karena itu membuat pengulangan dan penghafalan lebih cepat dan lebih efisien. Kedua, proses pemilihan apa yang digarisbawahi membantu dalam menhubungkan informasi baru dengan pengetahuan yang telah ada (Nur, 2008:27), akan tetapi, siswa tidak selalu menggunakan prosedur menggarisbawahi dengan efektif. Suatu kesalahan umum adalah siswa menggarisbawahi hampir semua kalimat. Kadang-kadang siswa juga menggarisbawahi kalimat atau informasi yang tidak relevan. Kelemahan strategi ini yang menyebabkan penilaian untuk pemahaman keseluruhan isi bacaan memiliki skor paling rendah.

\section{Respon Siswa Pada Penerapan Strategi Menggarisbawahi dan Strategi 3R}

Data skor hasil angket respon siswa menunjukkan perbedaan pada kelompok menggarisbawahi 3,46 dan 3,53 untuk kelompok 3R. Angket respon siswa meliputi aspek penilaian subyektif siswa terhadap proses pelaksanaan pembelajaran, kemampuan guru dan penilaian umum terhadap kemampuan siswa dalam menggunakan strategi.

Kategori respon siswa yang tergolong baik memberi arti bahwa motivasi siswa terhadap pembelajaran juga baik. Menurut Garner, et al (1991) dan Graham \& Golam (1991) dalam Nur (2008:3), siswa yang termotivasi untuk belajar sesuatu akan menggunakan proses kognitif yang lebih tinggi dalam mempelajari informasi baru itu, siswa tersebut akan menyerap dan mengendapkan informasi itu dengan lebih baik. 
Perbedaan Penguasaan Konsep dan Peta Konsep Siswa Antara Penerapan Strategi Menggarisbawahi dan Strategi 3R

Pada penerapan masing-masing strategi didapatkan peningkatan sebesar 39,4\% untuk kelompok strategi menggarisbawahi dan peningkatan sebesar $42,5 \%$ pada kelompok strategi 3R.

Peningkatan penguasaan konsep pada kedua kelompok menunjukkan bahwa kedua strategi yang merupakan strategi mengulang kompleks dapat memfasilitasi penerimaan informasi pada register penginderaan agar dapat berpindah ke memori jangka pendek dan selanjutnya ke memori jangka panjang. Melalui strategi mengulang informasi baru akan bertahan lebih lama dalam memori jangka pendek, karena semakin lama suatu butir informasi tinggal di dalam memori jangka pendek, semakin besar kemungkinan informasi itu akan ditransfer ke memori jangka panjang. Tanpa proses pengulangan, kemungkinan butir informasi itu akan hilang (Nur, 2008:12).

Berdasarkan analisis statistik (uji t) hasil pretes dan postes penguasaan konsep menunjukkan ada perbedaan yang signifikan. Skor gain ternormalisasi untuk kelompok strategi menggarisbawahi adalah 0,61 yang termasuk dalam kategori sedang dan untuk kelompok strategi 3R adalah 0,72 yang termasuk dalam kategori tinggi. Skor gain ternormalisasi dalam kategori tinggi untuk strategi 3R mengindikasikan bahwa strategi ini lebih efektif karena memiliki tahap resitasi dan reviu yang memaksimalkan jumlah penerimaan informasi(Kang et al, 2007 dalam McDaniel, 2009).

Berdasarkan hasil penilaian terhadap peta konsep yang dibuat siswa, juga tampak adanya peningkatan ratarata skor pada pretes dan postes. Skor rata-rata postes pada kedua kelompok lebih tinggi dibandingkan dengan skor rata-rata pretes. Dengan selisih sebesar 17,0 pada kelompok strategi menggarisbawahi dan 42,9 pada kelompok strategi 3R.

Peningkatan skor postes dari pretes untuk penguasaan konsep dan peta konsep juga mengindikasikan bahwa kedua strategi ini, yaitu menggarisbawahi dan 3R efektif tetapi strategi 3R lebih efisien. Selisih rata-rata skor postes dan pretes pada kelompok dengan strategi 3R yang lebih tinggi menunjukkan bahwa strategi 3R memiliki keunggulan dibandingkan dengan strategi menggarisbawahi pada kelompok lain. Adanya tahap-tahap spesifik (membacaresitasi-reviu) dalam strategi ini memandu siswa untuk menemukan informasi penting dalam bahan bacaan. Tahap resitasi menyediakan alat evaluasi bagi siswa untuk menilai pemahamannya sendiri pada tahap reviu (membaca kembali). Dan tahap akhir dari strategi ini dengan kegiatan membaca kembali merupakan suatu kondisi yang memaksimalkan penerimaan informasi (Kang et al, 2007 dalam McDaniel, 2009).

Hasil uji t menunjukkan tidak adanya perbedaan yang signifikan untuk skor peta konsep antara strategi menggarisbawahi dan strategi $3 \mathrm{R}$, walaupun skor postes lebih tinggi dari pada skor pretes untuk kedua strategi tersebut. Hal ini mengindikasikan bahwa perubahan struktur peta konsep pada pretes dan postes untuk kedua strategi adalah sama. Hasil tersebut juga menunjukkan bahwa kedua strategi sama dalam meningkatkan struktur peta konsep siswa. Siswa pada kedua kelompok strategi belum pernah mendapatkan pengajaran secara khusus tentang bagaimana membuat peta konsep, sedangkan penelitian ini hanya dilakukan dalam dua kali pertemuan sehingga latihan membuat peta konsep yang baik menjadi kurang.

Dilihat dari komponen peta konsep, maka komponen yang sama sekali tidak berkembang adalah komponen diagonal. Hubungan diagonal merupakan suatu komponen dalam peta konsep, karena menghubungkan peta konsep dengan konsep-konsep lain yang berbeda (Novak dan Cañas, 2008). Komponen ini mendapat bobot paling tinggi karena hubungan yang bermakna antara dua konsep yang berbeda merupakan bukti penting dari keutuhan pemahaman seseorang (Novak dan Gowin, 1984 dalam Ozdemir, 2005). Diagonal dalam peta konsep sangat penting untuk memfasilitasi kemampuan berpikir kreatif siswa selain struktur hirarkis peta konsep. Oleh karena itu, melatihkan siswa untuk membuat peta konsep dengan memenuhi komponen-komponennya secara tepat adalah sangat penting agar siswa terbiasa untuk melihat atau memahami suatu konsep secara utuh.

Membuat peta konsep memerlukan keterampilan untuk dapat mempresentasikan konsep dalam pemikiran menjadi gambaran yang dapat dipahami orang lain, oleh karena itu agar dapat membuat peta konsep yang baik, keterampilan ini perlu dilatihkan banyak kali. Hal ini sesuai dengan yang dinyatakan oleh Hilbert dan Renki (2007) bahwa untuk berhasil dalam membuat peta konsep para pebelajar harus merencanakan proses pembuatannya dan selama pembuatan peta konsep mereka harus berkonsentrasi pada hubungan antara konsep dan kata hubung yang sesuai. Selain itu mereka juga harus memantau kemanjuan perkembangan peta konsep mereka. Pebelajar yang lebih sering membuat peta konsep tampaknya lebih mudah melakukan proses tersebut dengan hasil yang lebih baik pula (Hillbert dan Renki, 2007).

Sebagai tambahan bahwa dalam penelitian ini peta konsep digunakan sebagai alat penilaian atau alat evaluasi, tetapi peta konsep sebenarnya juga dapat berfungsi sebagai strategi belajar yang termasuk dalam strategi organisasi. Strategi yang diajarkan pada penelitian 
ini, baik strategi menggarisbawahi maupun strategi 3R, keduanya merupakan strategi mengulang. Ketika struktur pemahaman siswa diukur dengan peta konsep yang merupakan strategi yang lebih kompleks dari strategi yang diajarkan, maka hasilnya adalah tidak menunjukkan perbedaan yang signifikan antara kedua kelompok eksperimen.

\section{SIMPULAN}

Dari hasil penelitian dapat disimpulkan bahwa antara penerapan strategi menggarisbawahi dan strategi 3R terdapat perbedaan untuk penguasaan konsep siswa, namun untuk kemampuan siswa dalam membuat peta konsep tidak berbeda.

Hasil yang lain menunjukkan bahwa kedua strategi dapat meningkatkan penguasaan konsep siswa dan kemampuan siswa dalam membuat peta konsep, namun strategi 3R lebih efektif. Penerapan RPP dalam proses pembelajaran teramati dapat terlaksana dengan sangat baik. Keterampilan siswa dalam menerapkan strategi dan respon siswa terhadap pembelajaran juga sangat baik.

Berdasarkan hasil di atas maka strategi 3R dapat dilatihkan kepada siswa sebagai alternatif untuk melatihkan strategi belajar yang mudah diterapkan. Respon positif dari siswa terhadap pembelajaran dengan strategi belajar merekomendasikan bahwa penerapan strategi belajar dapat lebih sering dilaksanakan oleh guru dalam kegiatan belajar mengajar dan diterapkan pada konsep-konsep lain yang memiliki karakteristik yang sama dengan materi Organisasi Kehidupan.Peta konsep dapat menggambarkan pemahaman konseptual siswa, oleh karena itu sangat baik kiranya jika pembuatan peta konsep diterapkan untuk alat evaluasi sebagai umpan balik bagi siswa dan guru.

\section{DAFTAR PUSTAKA}

Amir, M. F. 2006. Mengolah dan Membuat Interpretasi Hasil Olahan SPSS Untuk Penelitian Ilmiah. Jakarta: Edsa Mahkota.

Borich, G. D. 1994. Observation Skills for Effective Teaching. Ed. 2. New York: Macmillan Publishing Company.

Direktorat PSMP. 2010. Panduan Pelaksanaan Pembelajaran Matematika dan IPA dalam Bahasa Inggris di Rintisan SMP Bertaraf Internasional. Jakarta: Depdiknas

Hake, R.R. 1999. Analyzing Change/Gain Scores.http://www.physics.indiana.edu/ sdi/Analyzi ngChange-Gain.pdf

Hillbert, T.S. and Renki, A. 2007. Concept Mapping as a Follow-Up Strategy to Learning From Texts: What Characterizes Good and Poor Mappers?. Springer
Science+Business Media B. V. Instr Sci (2008) 36. p.p: 53-73. Versi elektronik.

Jihad, A. dan Haris, A. 2008. Evaluasi Pembelajaran. Yogyakarta: Multi Pressindo.

Nur, M. 2005. Strategi-strategi Belajar. Surabaya : UNESA - University Press

Nur, M. 2008. Model Pengajaran Langsung. Surabaya: PSMS UNESA

Nur, M. dan Wikandari, P. R. 2008. Pengajaran Berpusat Kepada Siswa dan Pendekatan Konstruktivis dalam Pengajaran. Surabaya: PSMS UNESA

Nur, M. 2008. Pemotivasian Siswa Untuk Belajar. Surabaya: PSMS UNESA

Nur, M., Wikandari, P.R. dan Sugiarto, B. 2008. Teoriteori Pembelajaran Kognitif. Surabaya: PSMS UNESA

Ozdemir, A. Ş. 2005. Analyzing Concept Map as an Assessment (Evaluation) Tool in Teaching Mathematics. Journal of Social Sciences 1 (3). p.p: 141-149. Diakses dari http://www.scipub.org/fulltext/jss13141-149 pada 20-08-2010.

Rowland, G. 2006. Biology AS \& A2. Essex: Pearson Education Limited.

Sukardi. 2007. Metodologi Penelitian Pendidikan: Kompetensi dan Praktiknya. Jakarta: P.T. Bumi Aksara.

Westwood, P. 2007. Learning and Learning Difficulties: A handbook for teachers. Victoria: Australian Council for Educational Research Ltd 